\title{
Macrozoobenthos structure in a temperate acid oligotrophic lake
}

\author{
Daria Mimier, Magdalena Godzich, Janusz Żbikowski* \\ Department of Hydrobiology, Faculty of Biology and Environmental Protection, \\ Nicolaus Copernicus University, Lwowska 1, 87-100 Toruń, Poland, \\ *e-mail: jzbikow@umk.pl
}

Received: 17 August 2017 / Accepted: 02 October 2017

\begin{abstract}
The aim of the paper was to evaluate the structure of macrozoobenthos in acid, oligotrophic Jasne Lake. The basic abiotic parameters of water and bottom sediments were also studied. The samples were taken on five dates: 25.11.1997 and 13.05., 01.07., 07.08. and 21.10. in 1998. The sampling sites were located in four clearly different zones of the lake bottom at depths: $5 \mathrm{~m}, 10 \mathrm{~m}$, $15 \mathrm{~m}$ and $19 \mathrm{~m}$.

The water transparency was very high $(11 \mathrm{~m})$ and water $\mathrm{pH}$ was extremely low (4.3). The oxygenation of the water near bottom was quite good up to a depth of $10 \mathrm{~m}$. Generally both the water content $(75.9 \%-96.1 \%)$ and organic matter content $(17.5 \%-76.5 \%)$ in the bottom sediments were relatively high and increased with the depth.

The taxonomic composition of the macrozoobenthos was similar to that of other acid water bodies, i.e. common, ubiquitous taxa dominated. Its species richness, diversity, and the density decreased as the depth increased but it is worth noting that the zone colonized by diverse and abundant macrozoobenthos extends to a depth of at least $10 \mathrm{~m}$. The dominant group of benthic fauna at a depth of $5 \mathrm{~m}$ were Chironomidae larvae (almost $80 \%$ of the total macrozoobenthos density). At this station Ceratopogonidae and Sialis sp. larvae were also relatively numerous. In turn, at depths of $10 \mathrm{~m}$ and $15 \mathrm{~m}$ Asellus aquaticus (Isopoda) (43\% and 57\%, respectively) and Trichoptera larvae (37\% and 21\%, respectively) dominated. Among the chironomids Pseudochironomus sp. and Chironomus sp. larvae prevailed. The only taxa characteristic of acidic waters were Stylodrilus heringianus (Oligochaeta) and Ablabesmyia monilis (Chironomidae).
\end{abstract}

Key words: bottom fauna, acid lake, high water transparency, bottom sediments, oligotrophic lake.

\section{Introduction}

Lakes are variable ecosystems characterized by progressive succession (Mikulski, 1982). The vast majority of lakes belong to harmonic water bodies subject to a process of natural or human-induced evolution from the oligotrophic to eutrophic state. However, natural lakes are also non-harmonic, i.e. ones having a strong dominance of one environmental factor (Kajak, 1988). The transition from a state of harmony to a disharmonic one can take place at different stages of succession (Choiński, 2007) and be a consequence of the interaction of factors coming from the catchment area or the effect of transformations taking place within the lake itself (Mikulski, 1982). The examples of non-harmonic lakes are acidotrophic lakes characterized by low $\mathrm{pH}$ of water.

The water acidification is usually an anthropogenic process, caused by substances of industrial origin (sulfuric acid, nitric acid) which reach water bodies with precipitation, as well as drainage from the catchment area (Kajak, 1988). Their influence on $\mathrm{pH}$ of water in a lake depends on its buffering capacity and the parent rock in the catchment area. Acidotrophic lakes are also characterized by a low concentration of $\mathrm{Ca}^{2+}$ ions in water, which prevents their acidic reaction from being neutralized. They occur predominantly in areas with a predominance of crystalline minerals in the substrate (Lampert \& Sommer, 1996). A common cause of the acidification of the waters is also 
the presence of acid humic substances in the catchment area of a given water body (Kajak, 1988).

The acidification of water bodies is a widespread phenomenon that has been extensively characterized in terms of chemical and biological changes (Carbone et al., 1998). The effect of acidification is, among other things, an increase in the solubility of aluminum, which is accompanied by the formation of toxic $\mathrm{Al}^{3+}$ ions. In addition, acidotrophic lakes often have also a low concentration of phosphates in the water, due to the binding of the aluminum ions with phosphate ions and their accumulation in the bottom sediments (Pliński, 1992). Thus, the $\mathrm{pH}$ of water significantly influences the functioning of the water body by shaping its physico-chemical properties (Lampert \& Sommer, 1996). In turn, it results in changes of biocoenosis of the reservoir, because the living organisms are directly dependent on the characteristics of the local environment and they clearly reflect the ecological conditions of the aquatic ecosystems they inhabit (Callisto et al., 2005; Behrend et al., 2012).

Investigations dealing with the effects of water acidification on biological systems are numerous. However, literature data concerning the relationship between structure of bottom fauna and the $\mathrm{pH}$ of the water are ambiguous. Some of them show that the structure and distribution of bottom fauna, like other groups of aquatic organisms in lakes with low $\mathrm{pH}$ of water, differ significantly from the structure of zoobenthos in neutral or alkaline reservoirs (Żytkowicz, 1982). According to Moiseenko (2005), as the $\mathrm{pH}$ of the water in the reservoirs decreases, as a rule, the number of macrozoobenthos species is rapidly decreases. In other studies the number of species decreased markedly with increasing acidity, while the biomass and density of bottom fauna showed no significant correlation with this parameter (Mossberg \& Nyberg, 1979; Meriläinen \& Hynynen, 1990). However, some investigations did not show influence of water $\mathrm{pH}$ on the diversity and the number of zoobenthos taxa (Collins et al., 1981; Kownacki et al., 2000; Kownacki et al., 2006). Dougherty and Morgan (1991), as well as Carbone et al. (1998) also reveal lack of overall changes in species richness and abundance related to acidity, although significant shifts in community composition occur.
Taking into account the above divergences and the very important role of bottom fauna in the functioning of water bodies (Graneli, 1979; Wiśniewski \& Planter, 1985; Svensson \& Leonardson, 1996), the aim of the paper was to evaluate the structure of bottom fauna and its horizontal changes in Jasne Lake, characterized by low $\mathrm{pH}$ and high transparency of water. We hypothesize that in the analyzed lake the structure of the macrozoobenthos and its horizontal changes will be different compared to harmonic, eutrophic lakes with low water transparency. We also assume that the benthic fauna of the lake will be dominated by the taxa characteristic of water with a low $\mathrm{pH}$.

\section{Study area}

Jasne Lake is located in Iława Lake District, which is the western part of the Masurian Lake District. In the distance of $50-100 \mathrm{~m}$, to the west and north, runs the boundary of the catchment area of the Drwęca river (which Jasne Lake belongs to) and the catchment area of the Liwa river. The lake lies at the highest altitude in this part of the lake district (108.6 $\mathrm{m}$ above sea level) (Żytkowicz, 1982), so the area of the direct catchment (12.6 ha) is not much greater than the lake area (10.7 ha), while the whole catchment is 8 times greater.

The basic morphometric data of Jasne Lake are presented in Table 1. It is a reservoir of glacial origin. On the west and north sides the banks are steep, while the rest are relatively gentle. The regular and deep bowl of the lake lies on the sand bed of about $30 \mathrm{~m}$ thickness. This layer separates the lake water from lower-lying beds of moraine clay, rich in soluble substances (Żytkowicz, 1982). Probably for this reason, as well as due to the lack of surface inflows, the small area of a typical forest catchment in relation to the lake area and the lack of agricultural crops in the immediate vicinity, Jasne Lake is characterized by exceptionally low trophic waters. Based on the total nitrogen $(0.514 \mathrm{mg}$ $\left.\mathrm{dm}^{-3}\right)$ and total phosphorus concentrations $\left(0.051 \mathrm{mg} \mathrm{dm}^{-3}\right)$ in water recorded in the $1990 \mathrm{~s}$, the reservoir should be classified into oligotrophic lakes (Kentzer, 2001).

Table 1. Basic morphometric data of Jasne Lake (Żytkowicz, 1982)

\begin{tabular}{|l|c|}
\hline \multicolumn{1}{|c|}{ Parameter } & Value \\
\hline Surface area (ha) & 10.74 \\
Volume $\left(\mathrm{m}^{3}\right)$ & 873300 \\
Maximum length (m) & 500 \\
Maximum width (m) & 342 \\
Maximum depth (m) & 19.8 \\
Mean depth (m) & 8.1 \\
\hline
\end{tabular}


The lake is surrounded by a dry coniferous forest with small patches of marshy coniferous forest and beech-pine forest. Due to the presence of forests in the immediate vicinity of the lake and its small area, the water dynamics is low. It is a dimictic lake and the thickness of its epilimnion reaches 6-8 m (Żytkowicz, 1982).

The basic properties which distinguish the lake are as follows: very low concentration of dissolved substances, low $\mathrm{pH}$ and high water transparency (Żytkowicz, 1982). First of all, attention should be paid to very low calcium content $\left(3.7 \mathrm{mg} \mathrm{dm}^{-3}\right)$, whose concentration is 7-20 times lower than in other lakes of Iława Lake District. Based on the water $\mathrm{pH}$, the lake should be classified into acidotrophic reservoirs. Its $\mathrm{pH}$ is extremely low (4.3), due to the previously mentioned low calcium concentration as well as the presence of peat deposits in the catchment area (Żytkowicz, 1982). In turn, the high water transparency is the consequence of the small amount of suspension in the water, which enables the penetration of light up to the lake bottom and results in a very good oxygenation of the water (Żytkowicz, 1982).

In this lake the littoral zone extends to a depth of approx. $15 \mathrm{~m}$. This zone can be divided into a typical sandy lit- toral, largely covered with coarse detritus, mainly of plant origin (up to a depth of 6-7 m) and the bottom overgrown with moss Drepanocladus fluitans (depth from 7 to $15 \mathrm{~m}$ ). From a depth of about 7-8 $\mathrm{m}$ the bottom is covered with an increasingly thick layer of muddy sediment.

In Jasne Lake, due to its acidotrophy, there is low diversity and abundance of phytoplankton, zooplankton, fish as well as aquatic plants (Żytkowicz, 1982). The main components of phytoplankton are unicellular flagellates, while the dominant group of zooplankton are Cladocera (Zieniewicz, 1995). Fish fauna of the lake is also poor in terms of quality and quantity. This group is represented almost exclusively by the low $\mathrm{pH}$ resistant perch (Perca fluviatilis) (Żytkowicz, 1982).

\section{Materials and methods}

The samples were taken on five dates: 25.11.1997 and 13.05., 01.07., 07.08. and 21.10. in 1998. The sampling sites were located in two transects at the following depths: $5 \mathrm{~m}, 10 \mathrm{~m}, 15 \mathrm{~m}$ and $19 \mathrm{~m}$ (Fig. 1). Due to the lack of sig-

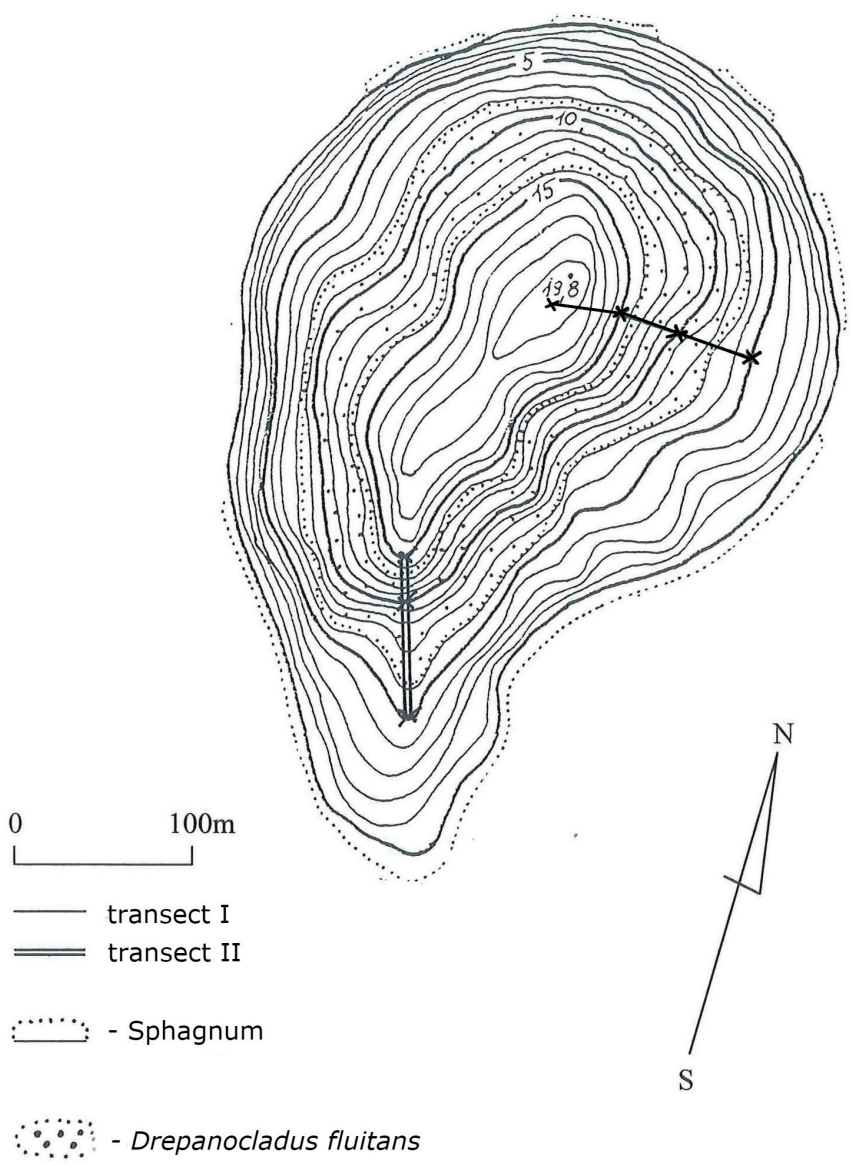

Figure 1. The bathymetric plan of Jasne Lake. The location of the sampling stations 
nificant differences in the macrozoobenthos structure and the measured parameters of the water and the bottom sediments between the transects, in this paper the mean values of the obtained results are shown. The sampling sites were located in four clearly different zones of the lake bottom. The stations at a depth of $5 \mathrm{~m}$ (1) were located in the gravelsandy littoral zone, characterized by the presence of a large amount of plant remains, mainly of allochthonous origin. The stations at a depth of $10 \mathrm{~m}$ (2) were located in the region of occurrence of moss Drepanocladus fluitans. The stations at a depth of $15 \mathrm{~m}$ (3) were located out of the mosscovered zone, where still single but already decaying individuals of moss were encountered. In turn, the station at the deepest part of the lake - $19 \mathrm{~m}$ (4) - was located in the muddy bottom zone completely devoid of plants.

To collect the bottom fauna we used the Ekman-Birge grab (catching area: $225 \mathrm{~cm}^{2}$ ). The samples were rinsed using a $0.5 \mathrm{~mm}$ sieve and preserved in $4 \%$ formaldehyde. To assess the fresh biomass of the macrozoobenthos, preserved animals were dried on blotting paper and weighed to the nearest $0.0001 \mathrm{~g}$ with an analytical scales PRL T A13 (Poland).

Together with the collection of the macrozoobenthos samples, several abiotic parameters of the water and sediments were determined. Water transparency was measured with a Secchi disc. Temperature and oxygen concentration in the near-bottom water layer (2-3 cm above the bottom) were measured with a MultiLine P4 (WTW GMBH, Weilheim Germany) Universal Pocket Sized Meter.

Selected parameters of the bottom sediments were measured in their surface layer $(0-5 \mathrm{~cm})$ taken by means of a Kajak core sampler. We determined water content in the bottom sediments (by their oven-drying to a constant mass at $104^{\circ} \mathrm{C}$ ) and the organic matter content in the sediments (by igniting dried sediments at $550^{\circ} \mathrm{C}$ for 2 hours).

\section{Results}

\section{Abiotic parameters}

The values of abiotic parameters of water and bottom sediments are shown in Table 2. Due to the very high values of Secchi disc visibility, the water transparency was measured only at the deepest sampling site, where on average it was $11.1 \mathrm{~m}$. The $\mathrm{pH}$ of the water at all stations was only 4.3. The water temperature above the bottom decreased with increasing depth - at a depth of $5 \mathrm{~m}$, the average temperature was $15.5^{\circ} \mathrm{C}$, while at $19 \mathrm{~m}$ it was half lower $\left(7.1^{\circ} \mathrm{C}\right)$. The oxygen concentration of the water above the bottom was comparable at stations 1 and 2 (7.4 and $7.7 \mathrm{mg} \mathrm{dm}^{-3}$, respectively) and more than twice as high as at stations 3 and 4 (3.0 and $2.6 \mathrm{mg} \mathrm{dm}^{-3}$, respectively). Generally both the water content and the organic matter content in the bottom sediments increased with depth. The greatest difference in respect of these two parameters at station 1 was found. In this zone the water content was $75.9 \%$, while organic matter content was $17.5 \%$ of dry mass of bottom sediments. At the other stations the values of the parameters in question were comparable. The water content of the sediments ranged from $95.4 \%$ to $96.1 \%$, while the organic matter content ranged from $68.5 \%$ to $76.5 \%$.

\section{Bottom fauna}

During the course of the study, 23 benthic macroinvertebrates taxa were found (Table 3 ). The number of taxa, as well as the diversity of the macrozoobenthos (Shannon index) decreased with increasing depth of the lake. At a depth of $5 \mathrm{~m}$ these values were: 19 and 2.54, while at a depth of $15 \mathrm{~m}: 6$ and 1.82, respectively. At the deepest station $(19 \mathrm{~m})$ no bottom fauna was recorded.

Table 2. Measured abiotic parameters of water and bottom sediments (average values) in the distinguished zones of Jasne Lake

\begin{tabular}{|c|c|c|c|c|c|}
\hline Parameter & Depth: & $5 \mathrm{~m}$ & $10 \mathrm{~m}$ & $15 \mathrm{~m}$ & $19 \mathrm{~m}$ \\
\hline $\begin{array}{l}\text { Water } \\
\text { Secchi depth (m) }\end{array}$ & & - & - & - & 11.1 \\
\hline $\mathrm{pH}$ & & 4.3 & 4.3 & 4.3 & 4.3 \\
\hline Temperature ${ }^{1}\left({ }^{\circ} \mathrm{C}\right)$ & & 15.5 & 12.5 & 8.4 & 7.1 \\
\hline Oxygen concentration ${ }^{1}\left(\mathrm{mg} \mathrm{dm}^{-3}\right)$ & & 7.4 & 7.7 & 3.0 & 2.6 \\
\hline $\begin{array}{l}\text { Bottom sediments } \\
\text { Water content }(\%)\end{array}$ & & 75.9 & 95.4 & 96.4 & 96.1 \\
\hline Organic matter content (\%) & & 17.5 & 68.5 & 72.5 & 76.5 \\
\hline
\end{tabular}

${ }^{1}$ the values measured 2-3 cm above the lake bottom. The Secchi depth was measured only at a depth of $19 \mathrm{~m}$ 
Table. 3. Taxonomic composition, total number of taxa and diversity, as well as average density (ind. $\mathrm{m}^{-2}$ ) of the macrozoobenthos in the distinguished zones of Jasne Lake

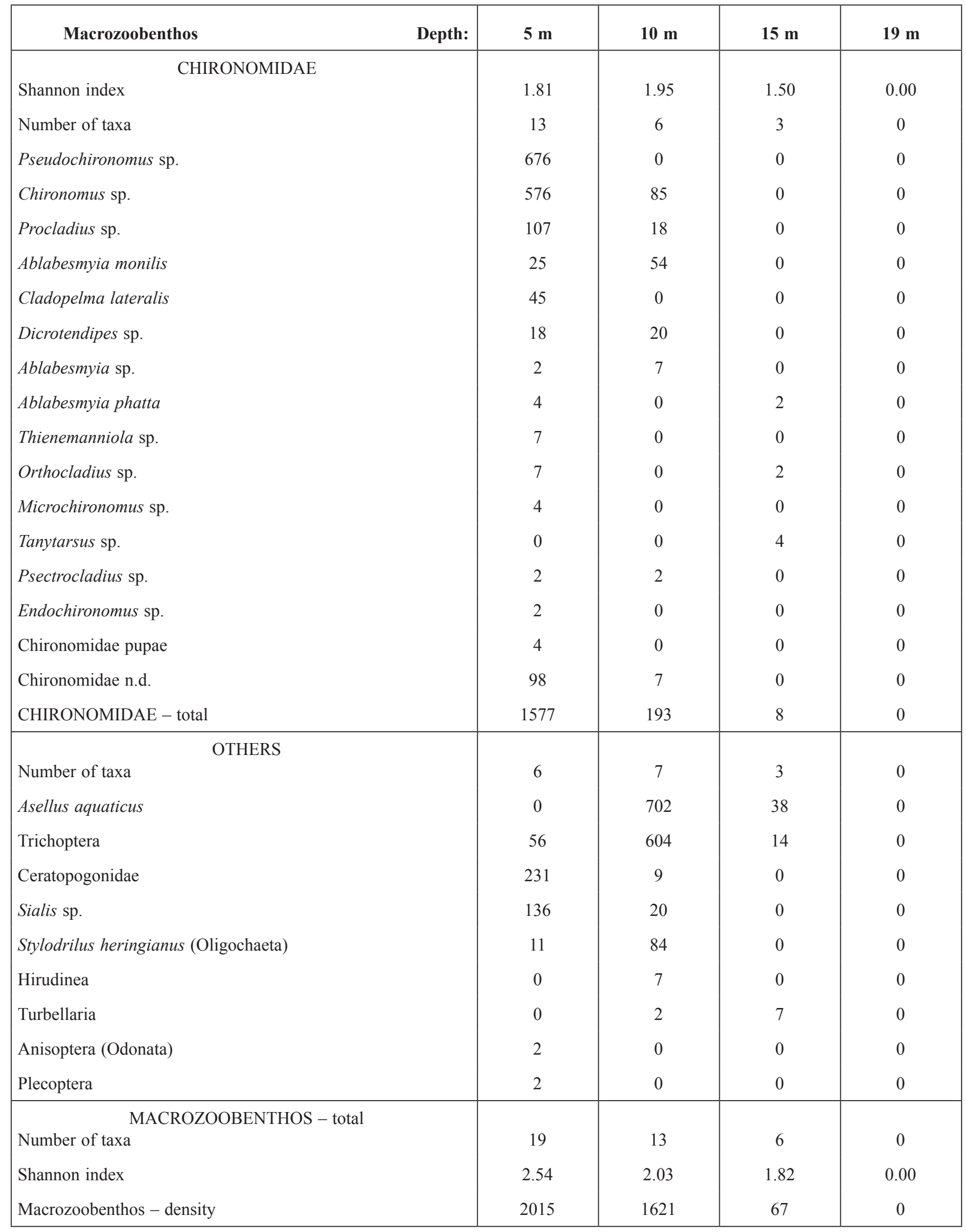


Among the Chironomidae larvae 14 taxa were distinguished. The number of taxa of this group of organisms decreased from 13 at a depth of $5 \mathrm{~m}$ to 3 at a depth of $15 \mathrm{~m}$, while the values of Shannon index were similar (range from 1.50 to 1.95) (Table 3). Chironomus sp. and Pseudochironomus sp. larvae predominated, the latter was found only at a depth of $5 \mathrm{~m}$. Both the density and the biomass of this group of zoobenthos reached the highest values at station 1 (1577 ind. $\mathrm{m}^{-2}$ and $2.00 \mathrm{~g} \mathrm{~m}^{-2}$, respectively) and decreased with increasing depth.

The density of total macrozoobenthos also decreased with increasing depth, however at stations 1 and 2 significantly higher values of this parameter were found (2015 and 1621 ind. $\mathrm{m}^{-2}$, respectively) compared to stations 3 and 4 (67 and 0 ind. $\mathrm{m}^{2}$, respectively).

The macrozoobenthos dominance structure based on the density was similar at stations 2 and 3 but completely different at station 1 (Fig. 2). At the latter the dominant group of the benthic fauna were Chironomidae larvae (almost $80 \%$ of the total macrozoobenthos density). At this station Ceratopogonidae and Sialis sp. larvae were also relatively numerous. In turn, at stations 2 and 3 Asellus aquaticus (Isopoda) (43\% and 57\%, respectively) and Trichoptera larvae (37\% and $21 \%$, respectively) dominated. The share of the Chironomidae larvae at these stations were identical and accounted for only $12 \%$ of the total macrozoobenthos density. The share of sole representative of Oligochaeta - Stylodrilus heringianus - was the highest at a depth of $10 \mathrm{~m}$.

The biomass of benthic fauna was correlated to their density. The values of this parameter at depths of $5 \mathrm{~m}$ and $10 \mathrm{~m}$ were significantly higher (6.87 and $11.45 \mathrm{~g}$ $\mathrm{m}^{-2}$, respectively), than at depths of $15 \mathrm{~m}$ and $19 \mathrm{~m}$ (0.99 and $0.00 \mathrm{~g} \mathrm{~m}^{-2}$, respectively) (Fig. 3). At station 1 Sialis sp. $(45 \%)$ predominated in this regard while the Chironomidae larvae, strong prevailing at this station in terms of density, constituted only $29 \%$ of the total zoobenthos biomass. As in the case of density, in terms of biomass at stations 2 and 3 Asellus aquaticus (45\% and 78\%, respectively) and Trichoptera larvae dominated.

\section{Discussion}

Jasne Lake is characterized by extremely low $\mathrm{pH}$ of the water. The value of this parameter decreased from 6.1 in 1961 to 4.3 in 1979-1998 (Żytkowicz, 1982). The acidification of the lake is crucial for its functioning, as it contributes to changes in other physico-chemical parameters of the water, which in turn affect the lake biocoenosis.

The water transparency in the lake under study was very high, due to the small amount of suspension in the water, which was associated with its acidification and low trophic level (Żytkowicz, 1982). High water transparency is a typical feature of acid lakes (Szkokan-Emilson et al., 2010; Wesolek et al., 2010a). The values of this parameter in eutrophic lakes are usually much smaller due to the intensive processes of biological production. The oxygenation of the water near bottom was quite good up to a depth of $10 \mathrm{~m}$. The highest values of oxygen concentration recorded at station 2 were probably related to the occurrence of moss Drepanocladus fluitans that produced oxygen during photosynthesis.

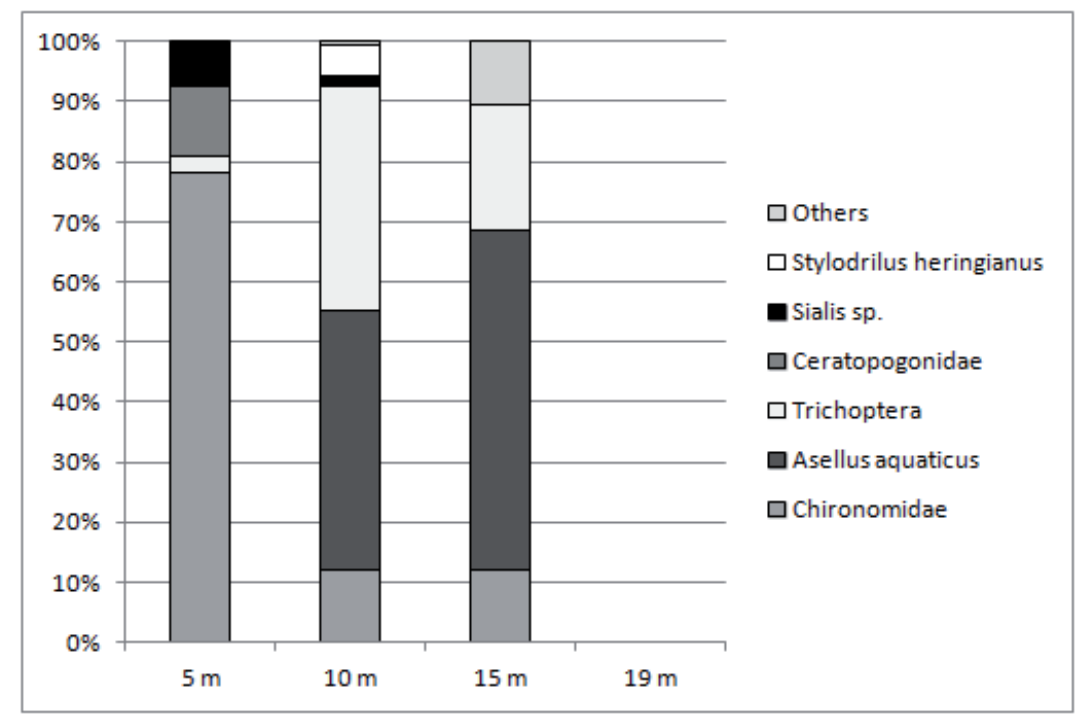

Figure 2. Percentage share of the particular taxonomic groups in the total density of macrozoobenthos in the distinguished zones of Jasne Lake 
The organic matter content in the bottom sediments of Jasne Lake was relatively high. It could be the consequence of the slow rate of mineralization of organic compounds. The low rate of organic matter decomposition in acid water bodies is also indicated by Kownacki et al. (2006) and Wesolek et al. (2010b). This may be due to the low abundance and metabolic activity of heterotrophic bacteria in the bottom sediments (Donderski \& Stopiński, 1977). However, Dermott et al. (1986) inform that the high organic matter content of lake sediments in poorly buffered and oligotropic lakes may be partly due to an increased percentage of refractory debris from terrestrial sources, rather than a reduction of sediment bacterial activity.

The water content in the bottom sediments in the studied lake was very high at all depths, which can be explained by high organic matter content in the sediments. As it is well known, organic matter is much more hydrated than mineral matter (Hakanson \& Jansson, 1983). Similar values of both discussed parameters of the bottom sediments were also found in other acid lakes (Dermott et al., 1986). The water and organic matter content in the sediments showed a positive correlation with the lake depth, which is characteristic of most of the water reservoirs.

The bottom fauna of Jasne Lake was represented by 23 taxa. A similar number of macrozoobenthos taxa was also found in many other acidotrophic lakes in the Czech Republic (Ungermanova et al., 2014), in the Canada (Dermott et al., 1986; McNicol et al., 1995; Reid et al., 1995; Parsons et al. Szkokan-Emilson et al., 2010; Wesolek et al., 2010a) and in the USA (Dougherty \& Morgan, 1991). On the other hand, in a significant number of acid lakes clearly lower number of bottom fauna taxa were also recorded (Dermott et al., 1986; Kownacki et al., 2006; Parsons et al., 2010; Szkokan-Emilson et al., 2010).

The species richness, the diversity, and the density of the macrozoobenthos decreased as the depth increased, which is typical feature of most water bodies. However, it is important to emphasize the differences in the horizontal changes of the bottom fauna in Jasne Lake compared to eutrophic lakes. The zoobenthos structure at station 1 (a depth of $5 \mathrm{~m}$ ) and at station 2 (a depth of $10 \mathrm{~m}$ ) was very similar in terms of diversity and above all abundance. In eutrophic lakes, the high diversity and abundance of the zoobenthos is generally limited to the shallow littoral zone (Kajak, 1988). By contrast, in Jasne Lake the zone colonized by diverse and abundant macrozoobenthos extends to a depth of at least $10 \mathrm{~m}$. The reason for the small changes in the diversity and abundance of the bottom fauna between stations 1 and 2 was probably good water oxygenation at both depths. The station 2 was located in the moss area of Drepanocladus fluitans, which, in addition to improved oxygen conditions and habitat heterogeneity also contributed to better nutritional conditions for zoobenthos. However, it should be noted that there is a clear difference in the dominance structure of bottom fauna between the stations 1 and 2, which may have been a consequence of the different quality of food for zoobenthos - coarse detritus at station 1 and moss at station 2. In turn, quantitatively and qualitatively poor bottom fauna at a depth of $15 \mathrm{~m}$ and their absence at a depth of $19 \mathrm{~m}$ could result from the low oxygen concentration over the bottom and the high water content in the sediments, impeding the existence of this group of organisms. According to Meriläinen

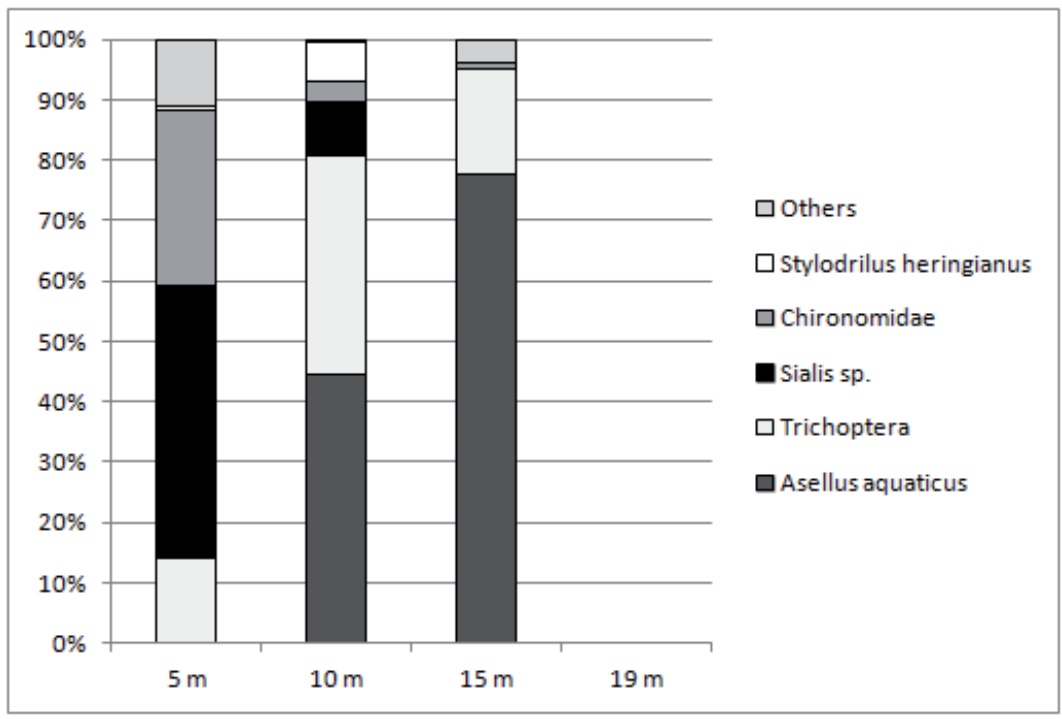

Figure 3. Percentage share of the particular taxonomic groups in the total biomass of the macrozoobenthos in the distinguished zones of Jasne Lake 
and Hynynen (1990) in deeper zones of acid lakes, diversity and abundance of benthic fauna is generally low.

The Chironomidae larvae were an important component of the bottom fauna of the studied lake. They also prevailed in acid Finnish (Meriläinen \& Hynynen, 1990) and Canadian lakes (Dermott et al., 1986). Several genera of Chironomidae larvae are tolerant of poor water conditions including increased acidity (Mackay \& Kersey, 1985; Lenat \& Barbour, 1994; Parsons et al., 2010). Meriläinen and Hynynen (1990) suggest that many chironomid species tolerate $\mathrm{pH}$ of $4-4.5$. Thus, they are common inhabitants of acid waters. Lento et al. (2012) also report that the share of this group of organisms increases with increasing of water acidification.

Among the chironomids Pseudochironomus sp. and Chironomus sp. larvae prevailed. A significant share of the latter was also reported in acid Canadian lakes (Dermott et al., 1986), American (Uutala, 1981), Sweden (Mossberg \& Nyberg, 1979) and other European lakes (Raddum \& Saether, 1981; Henrikson et al., 1982). Moreover, according to the authors cited its share increased with increasing acidification. Chironomus sp. is considered to be very acid tolerant often being the only taxon present in very acidic waters (Harp \& Campbell, 1967; Tomkiewicz \& Dunson, 1977; Dougherty \& Morgan, 1991). In Jasne Lake, there were also relatively numerous taxa such as: Procladius sp., Ablabesmyia monilis, Cladopelma lateralis and Dicrotendipes sp. These taxa in significant densities also in acidic Canadian (Dermott et al., 1986; Carbone et al., 1998) and American lakes (Dougherty \& Morgan, 1991) were found.

In conclusion, in Jasne Lake, as in others acidotrophic as well as eutrophic lakes, among Chironomidae larvae common, ubiquitous taxa predominated. The numerous occurrences of these taxa in the lake under study testify to their tolerance also for low $\mathrm{pH}$ of water. It is worth noting that among the chironomids we did not find the presence of taxa, characteristic only for acid waters (except for $A b$ labesmyia monilis).

There was relatively high density (but only at station 1) of Ceratopogonidae larvae in Jasne Lake. These organisms are also commonly found in other acid water bodies due to their resistance to low water $\mathrm{pH}$ (Carbone et al., 1998). The cited authors, studying the Canadian lakes, significantly higher densities of this group of animals in acidotrophic than in neutral lakes have noted.

The Trichoptera larvae and Asellus aquaticus were the next two important groups of the macrozoobenthos, prevailing in density at depths of $10 \mathrm{~m}$ and $15 \mathrm{~m}$ of the studied lake. According to Stańczykowska (1979), they are mainly herbivores, which do not tolerate low water oxygenation, typical for a littoral zone. The occurrence of these animals at relatively large depths can be explained by good food and oxygen conditions resulting from the presence of Drepanocladus fluitans at the lake bottom. The moss can also provide a shelter for these organisms. In addition, A. aquaticus tolerates low water $\mathrm{pH}$ and is relatively abundant in acid waters (Økland \& Økland, 1986; Moiseenko, 2005). However, Trichoptera larvae do not belong to invertebrates commonly found in acid water bodies and their share in the abundance of bottom fauna decreases with increasing acidification of water in a reservoir (Lento et al., 2012). Thus, so numerous occurrences of the Trichoptera larvae in such a low $\mathrm{pH}$ lake can be surprising. It may have been beneficial for this group to have Drepanocladus fluitans moss. It seems that the discussed group of zoobenthos

Table 4. The average biomass $\left(\mathrm{g} \mathrm{m}^{-2}\right)$ of the macrozoobenthos in the distinguished zones of Jasne Lake

\begin{tabular}{|c|c|c|c|c|c|}
\hline Macrozoobenthos & Depth: & $5 \mathrm{~m}$ & $1 \mathrm{~m}$ & $15 \mathrm{~m}$ & $19 \mathrm{~m}$ \\
\hline Asellus aquaticus & & 0.00 & 5.10 & 0.77 & 0.00 \\
\hline Trichoptera & & 0.96 & 4.13 & 0.17 & 0.00 \\
\hline Sialis sp. & & 3.10 & 1.02 & 0.00 & 0.00 \\
\hline Chironomidae & & 2.00 & 0.39 & 0.01 & 0.00 \\
\hline Stylodrilus heringianus (Oligochaeta) & & 0.06 & 0.74 & 0.00 & 0.00 \\
\hline Plecoptera & & 0.41 & 0.00 & 0.00 & 0.00 \\
\hline Ceratopogonidae & & 0.23 & 0.03 & 0.00 & 0.00 \\
\hline Anisoptera (Odonata) & & 0.11 & 0.00 & 0.00 & 0.00 \\
\hline Turbellaria & & 0.00 & 0.02 & 0.04 & 0.00 \\
\hline Hirudinea & & 0.00 & 0.02 & 0.00 & 0.00 \\
\hline MACROZOOBENTHOS - total & & 6.87 & 11.45 & 0.99 & 0.00 \\
\hline
\end{tabular}


should be identified to a species level, which could allow the identification of acid-tolerant species.

Stylodrilus heringianus was the only representative of Oligochaeta in Jasne Lake. It is a species characteristic for low-pH oligotrophic lakes (Rosenberg \& Resh, 1993). There were no other representatives of this group of organisms most likely due to the very acid water. Although many Oligochaeta taxa are considered quite acid-tolerant (Parsons, 1968; Roff \& Kwiatkowski, 1977; Lento et al., 2008; Parsons et al., 2010), however, in reservoirs with $\mathrm{pH}$ below 5 , oligochaetes are now present at very low densities (Ungermanova et al., 2014). The availability of organic matter due to the reduced abundance and activity of the bacteria in the bottom sediments may also limit the development of this group of definitely detritivores animals.

It is also worth noting that there were no Mollusca representatives in the studied lake, a group of aquatic organisms, which are an important part of macrozoobenthos of harmonic lakes. This is characteristic of most acid water bodies. The presence of this group of animals has also not been reported in acid Canadian (Dermott et al., 1986) and American lakes (Dougherty \& Morgan, 1991), while in Swedish (Mossberg \& Nyberg, 1979) and Czech lakes (Ungermanova et al., 2014) Mollusca occurred in very small densities. The Mollusc's high sensitivity to acidification is also reported by Moiseenko (2005) and many other authors (Meriläinen \& Hynynen, 1990; Muniz, 1991; Raddum \& Skjelkvele, 2001). The main factor limiting the development of Mollusca in acid water bodies is shortage of calcium, necessary for building their shells (Moiseenko, 2005).

This study did not reveal the presence of Chaoborus sp. larvae in Jasne Lake. There are conflicting information in the literature on the occurrence of this taxon in acid water bodies. Ungermanova et al. (2014) indicate the absence or low densities of Chaoborus larvae in low-pH waters. On the other hand, according to some authors these organisms are commonly found in highly acidified reservoirs (Walker et al., 1985; Dermott et al., 1986). In turn, Havas \& Rosseland (1995) state that Chaoborus sp. tolerates acid water, but probably due to the limited availability of food (zooplankton) does not exist in a such reservoirs. Due to the small abundance of fish in Jasne Lake, it is rather unlikely that the absence of Chaoborus larvae may be a consequence of the high water transparency increasing the availability of these larvae for fish.

\section{Conclusions}

The taxonomic composition of the macrozoobenthos of acid, oligotrophic Jasne Lake was similar to that of other acid reservoirs, i.e. common, ubiquitous taxa dominated. The only taxa characteristic of acid waters were Stylodrilus heringianus (Oligochaeta) and Ablabesmyia monilis (Chi- ronomidae). On the other hand the little surprise could be relatively large abundance of Trichoptera larvae - organisms considered to be sensitive to low $\mathrm{pH}$ water.

The horizontal changes of the macrozoobenthos structure in Jasne Lake were different than in "typical" eutrophic lakes. Owing to the good oxygen conditions and habitat heterogeneity, this lake is characterized by diverse and abundant bottom fauna even at relatively large depths.

\section{References}

Behrend R.D.L., Takeda A. M., Gomes L.C. \& Fernandes S.E.P., 2012, Using oligochaeta assemblages as an indicator of environmental changes, Braz. J. Biol. 72: 873-884.

Callisto M., Goulart M., Barbosa F.A.R. \& Rocha O., 2005, Biodiversity assessment of benthic macroinvertebrates along a reservoir cascade in the lower São Francisco river (northeastern Brazil), Braz. J. Biol. 65: 229-240.

Carbone J., Keller W. \& Griffiths R.W., 1998, Effects of changes in acidity on aquatic insects in rocky litoral habitats of lakes near Sudbury, Ontario, Restor. Ecol. 6: 376-389.

Choiński A., 2007, Limnologia fizyczna Polski [Physical limnology of Poland], Wyd. Naukowe UAM, Poznań.

Dermott R., Kelso J.R.M. \& Douglas A., 1986, The benthic fauna of 41 acid sensitive headwater lakes in North Central Ontario, Water, Air, Soil Poll. 28: 283-292.

Donderski W. \& Stopiński M., 1977, Dehydrogenase activity in bottom sediments of Tyree lakes, Acta Microbiol, Polonica 26 (1): 95-103.

Dougherty J.E. \& Morgan M.D., 1991, Benthic community response (primarily Chironomidae) to nutrient enrichment and alkalinization in shallow, soft water humic lakes, Hydrobiologia 215 (1): 73-82.

Graneli W., 1979, The influence of Chironomus plumosus larvae on the oxygen uptake of sedyment, Archiv für Hydrobiology 87: 385-403.

Hakanson L., Jansson M., 1983. Principles of lake sedimentology, Springer-Verlag, Berlin-New York.

Harp G.L. \& Campbell R.S., 1967, The distribution of Tendipes plumosus (Linné) in mineral acid water, Limnol. Oceanogr. 12(2): 260-263.

Havas M. \& Rosseland B.O., 1995, Response of zooplankton, benthos, and fish to acidification: an overview, Water, Air, Soil Poll. 85(1): 51-62.

Henrikson L., Oloffson J.B. \& Oscarson H.G., 1982, The impast of acidification on Chironomidae (Diptera) as indicated by subfossil stratification, Hydrobiologia 86 : 223-229.

Kajak Z., 1988, Hydrobiologia - Limnologia. Ekosystemy wód śródlądowych [Hydrobiology - Limnology. Inland water ecosystems], PWN, Warszawa. 
Kentzer A., 2001, Fosfor i jego biologicznie dostępne frakcje w osadach jezior różnej trofii, Rozprawa habilitacyjna [Phosphorus and its biologically available fractions in sediments of lakes with varied trophic conditions, Habilitation Thesis], UMK, Toruń.

Kownacki A., Dumnicka E., Kwandrans J., Galas J \& Ollik M., 2006, Benthic communities in relation to environmental factors in small high mountain ponds threatened by air pollutants, Boreal Environ. Res. 11: 481-492.

Kownacki A., Galas J., Dumnicka E. \& Mielewczyk S., 2000, Invertebrate communities in permanent and temporary high mountain lakes (Tatra Mts), Annls Limnol. 36: 181-188.

Lampert W., Sommer U., 1996, Ekologia wód śródlądowych [Ecology of inland waters], PWN, Warszawa.

Lenat D.R. \& Barbour M.T., 1994, Using benthic macroinvertebrate community structure for rapid, cost-effective, water quality monitoring: Rapid bioassessment, [in:] Biological Monitoring of Aquatic Systems, S.L. Loeb, A. Spacie (eds), Lewis Publishers, CRC Press, Inc., Boca Raton: 187-215.

Lento J., Dillon P.J. \& Somers K.M., 2012, Evaluating long-term trends in littoral benthic macroinvertebrate communities of lakes recovering from acid deposition, Environ. Monit. Assess. 184: 7175-7187.

Lento J., Dillon P.J., Somers K.M. \& Reid R.A., 2008, Changes in littoral benthic macroinvertebrate communities in relation to water chemistry in 17 Precambrian Shield Lakes, Can. J. Fish. Aquat. Sci. 65: 906-918.

Mackay R.J. \& Kersey K.E., 1985, A preliminary study of aquatic insect communities and leaf decomposition in acid streams near Dorset, Ontario, Hydrobiologia 122: 3-11.

McNicol D.K., Becndell B.E. \& Mallory M.L., 1995, Evaluating macroinvertebrate responses to recovery from acidification in small lakes in Ontario, Canada, Water, Air, Soil Poll. 85 (2): 451-456.

Meriläinen J.J. \& Hynynen J., 1990, Benthic invertebrates in relation to acidity in Finnish forest lakes, [in:] Acidification in Finland, P. Kauppi, P. Anttila \& K. Kenttämies (eds), Springer-Verlag, Berlin, Heidelberg, New York: 1029-1049.

Mikulski J., 1982, Biologia wód śródlądowych [Biology of inland waters], PWN, Warszawa.

Moiseenko T.I., 2005, Effects of acidification on aquatic ecosystems, Russian Journal of Ecology 36(2): 93-102.

Mossberg P. \& Nyberg P., 1979, Bottom fauna of small acid forest lakes, Rep. Inst. Freshw. Res. Drottningholm 58: 77-87.

Muniz I.P., 1991, Freshwater Acidification: Its Effects on Species and Communities of Freshwater Microbes, Plants and Animals, Proceedings of the Royal Society of Edinburgh 97B: 227-254.
Økland J. \& Økland K.A., 1986, Effects of acid deposition on benthic animals in lakes and streams, Experientia 42: 471-486.

Parsons B.G., Watmough S.A., Dillon P.J. \& Somers K.M., 2010, Relationships between lake water chemistry and benthic macroinvertebrates in the Athabasca Oil Sands Region, Alberta, J. Limnol. 69(1): 118-125.

Parsons J.D., 1968, The effects of acid strip-mine effluents on the ecology of a stream, Arch. Hydrobiol. 65: 25-50.

Pliński M., 1992, Hydrobiologia ogólna [General hydrobiology], Uniwersytet Gdański, Gdańsk.

Raddum G.G. \& Sæther O.A., 1981, Chironomid communities in Norwegian lakes with different degrees of acidification, Verh. Int. Verein. Limnol. 21: 399405.

Raddum G.G. \& Skjelkvale B.L., 2001, Critical loads of acidifying compounds on invertebrates in different ecoregions of Europe, Water, Air, Soil Poll. 130: 1131-1136.

Reid R.A., Somers K.M. \& David S.M., 1995, Spatial and temporal variation in littoral-zone benthic invertebrates from three south-central Ontario lakes, Can. J. Fish. Aquae. Sci. 52: 1406-1420.

Rejewski M., 1971, Szkic florystyczno-fitosocjologiczny jeziora Jasnego [Floristic and phytosociological draft for Lake Jasne], Limnological Papers, UMK, 6: 59-67.

Roff J.C. \& Kwiatkowski R.E., 1977, Zooplankton and zoobentos communities of selected northern Ontario lakes of different acidities, Can. J. Zool. 55(6): 899911.

Rosenberg D. \& Resh H., 1993, Freshwater biomonitoring and benthic macroinvertebrates, Chapman \& Hall, New York.

Stańczykowska A., 1979, Zwierzęta bezkręgowe naszych wód [Invertebrates of our waters], Wydawnictwa Szkolne i Pedagogiczne, Warszawa.

Svensson J.M. \& Leonardson L., 1996, Effects of bioturbation by tube-dwelling chironomids larvae on oxygen uptake and denitrification in eutrophic lake sediments, Fresh. Biol. 35: 289-300.

Szkokan-Emilson E. J., Wesolek B. E., Gunn J. M., Sarrazin-Delay Ch., Bedore J., Chan F., Garreau D., O'Grady A. \& Robinson Ch., 2010, Recovery of benthic invertebrate communities from acidification in Killarney Park lakes, Environ. Monit. Assess. 166: 293-302.

Tomkiewicz S.M., Jr. \& Dunson W.A., 1977, Aquatic insect diversity and biomass in a stream marginally polluted by acid strip-mine drainage, Water Res. 11: 397-402.

Ungermanová L., Kolaříková K., Stuchlík E., Senoo T., Horecký J., Kopáček J., Chvojka P., Tátosová J., Bitušík P. \& Fjellheim A., 2014, Littoral macroinvertebrates of acidified lakes in the Bohemian Forest, Biologia 69 (9): 1190-1201. 
Uutala A.J., 1981, Competition and secondary production of the chironomid (Diptera) community in two lakes in the Adirondack mountain region, [in:] Effects of Acidic Precipitation on Benthos, R. Singer (ed.), North American Benthological Society, New York: 139-154.

Walker I.R., Fernando C.H. \& Paterson C.G., 1985, Associations of Chironomidae (Diptera) of shallow, acid, humic lakes and bog pools in Atlantic Canada, and a comparison with an earlier paleoecological investigation, Hydrobiologia 120(1): 11-22.

Wesolek B.E., Genrich E.K., Gunn J.M. \& Somers K.M., 2010a, Use of littoral benthic invertebrates to assess factors affecting biological recovery of acid- and metaldamaged lakes, J. N. Am. Benthol. Soc. 29(2): 572-585.

Wesolek B.E., Szkokan-Emilson E.J. \& Gunn J.M., 2010b, Assessment of Littoral Benthic Invertebrate Commu- nities at the Land-Water Interface in Lakes Recovering from Severe Acid- and Metal-Damage, Hum. Ecol. Risk Assess. 16: 536-559.

Wiśniewski R. \& Planter M., 1985, Exchange of phosphorus across the sediment-water interface (with special attention to the influence of biotic factors) in several lakes of different trophic status, Verhandlungen der Internationalen Vereinigung für Limnologie 22: 33453349.

Zieniewicz L., 1995, Hydrobiologia jeziora Jasnego ze szczególnym uwzględnieniem zooplanktonu, Praca magisterska [Hydrobiology of Lake Jasne with particular emphasis on zooplankton, Master Thesis], UMK, Torun.

Żytkowicz R., 1982, Characteristics of the environment of the Jasne Lake, Limnological Papers 13: 51-63. 